\title{
Recent advances in understanding vertebrate segmentation
}

\section{[version 1; peer review: 3 approved]}

\author{
Tomás Pais-de-Azevedo ${ }^{1,2^{*}}$, Ramiro Magno ${ }^{1-3^{*}}$, Isabel Duarte ${ }^{1,2}$, \\ Isabel Palmeirim (iD) 1,2,4
}

${ }^{1}$ Algarve Biomedical Center, Faro, Portugal

${ }^{2}$ CBMR, Centre for Biomedical Research, University of Algarve, Faro, Portugal

${ }^{3}$ Theoretical Biology and Bioinformatics, Utrecht University, Utrecht, The Netherlands

${ }^{4}$ Department of Biomedical Sciences and Medicine, University of Algarve, Faro, Portugal

* Equal contributors

V1 First published: 23 Jan 2018, 7(F1000 Faculty Rev):97

https://doi.org/10.12688/f1000research.12369.1

Latest published: 23 Jan 2018, 7(F1000 Faculty Rev):97

https://doi.org/10.12688/f1000research.12369.1

\section{Abstract}

Segmentation is the partitioning of the body axis into a series of repeating units or segments. This widespread body plan is found in annelids, arthropods, and chordates, showing it to be a successful developmental strategy for growing and generating diverse morphology and anatomy. Segmentation has been extensively studied over the years. Forty years ago, Cooke and Zeeman published the Clock and Wavefront model, creating a theoretical framework of how developing cells could acquire and keep temporal and spatial information in order to generate a segmented pattern. Twenty years later, in 1997, Palmeirim and co-workers found the first clock gene whose oscillatory expression pattern fitted within Cooke and Zeeman's model. Currently, in 2017, new experimental techniques, such as new ex vivo experimental models, real-time imaging of gene expression, live single cell tracking, and simplified transgenics approaches, are revealing some of the fine details of the molecular processes underlying the inner workings of the segmentation mechanisms, bringing new insights into this fundamental process. Here we review and discuss new emerging views that further our understanding of the vertebrate segmentation clock, with a particular emphasis on recent publications that challenge and/or complement the currently accepted Clock and Wavefront model.

\section{Keywords}

Segmentation, Vertebrate, Somitogenesis, Clock, Wavefront, Embryo, Oscillation

\section{Open Peer Review

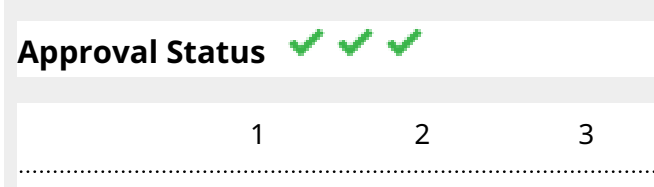 \\ version 1 \\ 23 Jan 2018 \\ Faculty Reviews are review articles written by the prestigious Members of Faculty Opinions. The articles are commissioned and peer reviewed before publication to ensure that the final, published version is comprehensive and accessible. The reviewers who approved the final version are listed with their names and affiliations. \\ 1. Robb Krumlauf, Stowers Institute for Medical Research, Kansas City, USA \\ 2. Michael Akam, University of Cambridge, \\ Cambridge, UK \\ 3. Yoshiko Takahashi, Kyoto University, Kyoto, \\ Japan}

Any comments on the article can be found at the end of the article. 
Corresponding author: Isabel Palmeirim (ipalmeirim@gmail.com)

Author roles: Pais-de-Azevedo T: Writing - Original Draft Preparation, Writing - Review \& Editing; Magno R: Writing - Original Draft Preparation, Writing - Review \& Editing; Duarte I: Writing - Original Draft Preparation, Writing - Review \& Editing; Palmeirim I: Conceptualization, Writing - Original Draft Preparation, Writing - Review \& Editing

Competing interests: No competing interests were disclosed.

Grant information: This work has been supported by the Portuguese Fundação para a Ciência e Tecnologia, fellowships SFRH/BD/84825/2012 to TPA, SFRH/BD/32966/2006 to RM, and PTDC/BEX-BID/5410/2014 to ID, and grants PTDC/BIM-MED/1063/2012 to IP and UID/BIM/04773/2013 to CBMR.

The funders had no role in study design, data collection and analysis, decision to publish, or preparation of the manuscript.

Copyright: @ 2018 Pais-de-Azevedo T et al. This is an open access article distributed under the terms of the Creative Commons Attribution License, which permits unrestricted use, distribution, and reproduction in any medium, provided the original work is properly cited.

How to cite this article: Pais-de-Azevedo T, Magno R, Duarte I and Palmeirim I. Recent advances in understanding vertebrate segmentation [version 1; peer review: 3 approved] F1000Research 2018, 7(F1000 Faculty Rev):97 https://doi.org/10.12688/f1000research.12369.1

First published: 23 Jan 2018, 7(F1000 Faculty Rev):97 https://doi.org/10.12688/f1000research.12369.1 


\section{Introduction}

Development is the process by which multicellular organisms start out as just one cell, multiply into millions of others that biochemically communicate with each other, rearrange their positioning, and even die in a programmed way. Embryo segmentation represents a particularly interesting phase of development, where a collection of physical, chemical, and biochemical events are successfully orchestrated in space and time in order to develop a fully grown organism.

Segmentation is the partitioning of the body axis into a series of repeating units or segments. In vertebrates, this process occurs in the embryo by subdivision of the presomitic mesoderm (PSM) into metameric structures termed somites, although other segmented systems exist in vertebrates (for an excellent review on this subject, see Graham et al. ${ }^{1}$ ). Segments in vertebrate embryos were first documented by the Italian biologist Marcello Malpighi in the 17th century $^{2}$, but, according to Verbout ${ }^{3}$, it was not until the work of Francis Balfour in the late 19th century that the term "somite" (mesoblastic somites in the original writing) was first used to describe them ${ }^{4}$. Somites form sequentially from rostral to caudal along the anterior-posterior (A-P) axis of the embryo, budding off in bilateral pairs from the unsegmented paraxial mesoderm on either side of the neural tube. These simple structures contain the precursor cells of the axial skeleton, musculature, connective tissue, blood vessel endothelium, and dermis of the vertebrate trunk, as well as muscles of the limbs ${ }^{5}$. Each segment will give rise to a somite-base unit, each connected to the brain via individual nerve structures, allowing an organized projection of the A-P adult body in the brain, which is crucial for an optimized central/peripheral communication in the organism.

In this article, we review some of the recent progress made on the study of segmentation. We start by providing an overview of the evolution of segmentation in the animal kingdom, briefly discussing the current hypotheses for its origin. Then we discuss the mechanism of segmentation. We briefly introduce the 40-year-old model of somitogenesis - the Clock and Wavefront model—and discuss how recent studies have been reshaping its original formulation. We finish by providing a list of open questions. The brief nature of this review precludes it from being comprehensive, since not all important developments could be discussed in such a short format. Accordingly, we sincerely apologize to all authors whose relevant work is not cited for space considerations.

\section{Origin and evolution of segmentation}

Overt body segmentation is considered a main evolutionary innovation occurring in three major animal phyla-annelids, arthropods, and chordates (reviewed in 6). By the end of the 19th century, these classical segmentation processes were viewed as homologous ${ }^{6}$. However, this assumption has been challenged by two subsequent scientific findings. Firstly, the advent of phylogenetic analysis showed that these clades are evolutionarily more distant to each other than to other unsegmented taxa $a^{7,8}$. Secondly, the majority of segmented animals present a sequential mode of segmentation, where oscillations combined with embryo growth yield a rostral to caudal sequence of segments. Please note, however, that arthropods

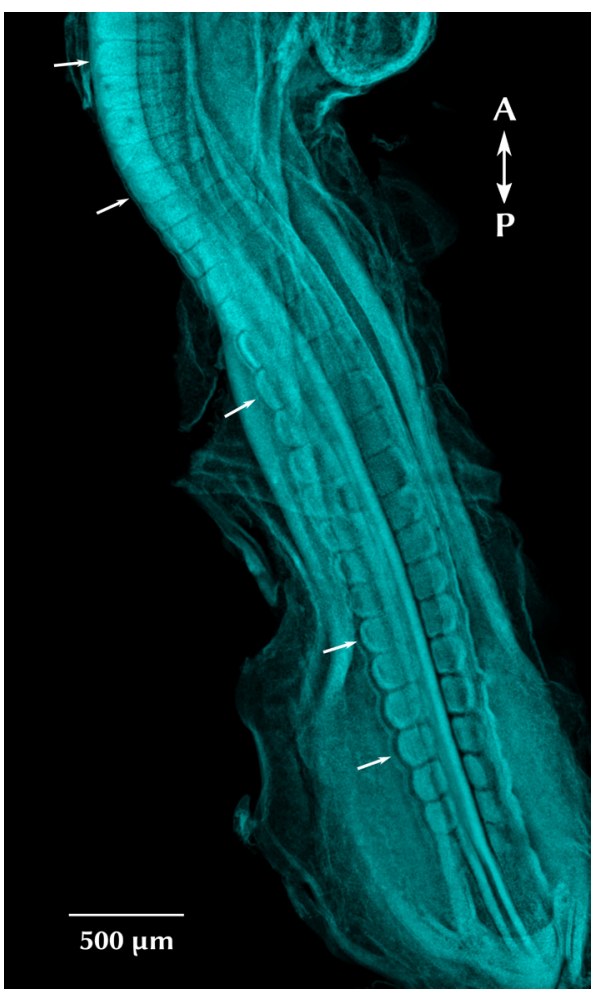

Figure 1. Chick embryo showing the segmented pattern along the anterior-posterior (A-P) axis. Embryo stage $\mathrm{HH} 17$, corresponding to 30 pairs of somites (age 52-64 hours). Dorsal view, stained with DAPI (cyan). Arrows indicate individual somites in different maturation stages.

present alternative modes of segmentation, which are discussed elsewhere ${ }^{9-11}$.

These observations raise (at least) two intriguing questions: did the segmented body plan evolve once or multiple times, and how (and why) did the simultaneous segmentation evolve? Two alternative hypotheses have been postulated to address these questions (for reviews, see 6,12-14): (i) either sequential segmentation is an ancestral characteristic present in the last common ancestor of bilaterian animals, which remained conserved in the three segmented taxa and lost in all others ${ }^{15,16}$ (with the corollary that the simultaneous segmentation is derived from the sequential one) or (ii) segmentation arose separately in each of the three lineages and is therefore an example of convergent evolution. Different lines of evidence claim to corroborate each of these possibilities. For instance, some argue that the similar molecular pathways found in sequential segmentation of arthropods is indicative of homology ${ }^{17}$; others suggest that these similarities may just be a consequence of the pleiotropy of signaling pathways such as Delta-Notch and thus misleading in this debate. Another interesting hypothesis is the possibility that these molecular similarities have been co-opted from a mechanism of posterior growth present in the common ancestor between the two 
groups ${ }^{18,19}$. This issue is very much still an open question. Accordingly, more than just asking how the different mechanisms of segmentation are related, one could ask: what are the main principles underlying them, what developmental and evolutionary changes lead to them, or even if there are other possible mechanisms we have not considered yet ${ }^{20}$. These questions can be addressed by both broadening the diversity of organisms used to study segmentation ${ }^{21}$ and exploring the potential of using computational evolution and synthetic biology ${ }^{22,23,24}$ to generate and test hypotheses (for an excellent example of a comprehensive theoretical study on the evolution of segmentation, see 16).

\section{The mechanism of segmentation}

\section{The Clock and Wavefront model}

In 1976, a theoretical model was proposed by Cooke and Zeeman to explain the dynamics of somitogenesis-the Clock and Wavefront model ${ }^{25}$. This model proposes that cells of the PSM present an internal molecular oscillator-the clock-which is paired with a wavefront of cell differentiation progressing caudally as the embryo body axis elongates. This first conceptual model provided a possible explanation for how the temporal dynamics of a clock could be translated into a spatial pattern of somites.

\section{The molecular segmentation clock}

Twenty years later, Palmeirim et al. ${ }^{26}$ showed that $c$-hairyl, an avian homologue of the Drosophila hairy gene, was expressed dynamically in the PSM in a tissue-autonomous manner. Pulses of c-hairyl occur in individual PSM cells, with a 90-minute period. The fact that the individual PSM cells along the A-P axis are in different phases of the gene expression cycle (reviewed in 27) creates a kinematic wave (a wave in which transport is absent or negligible) of gene expression that sweeps rostrally, arresting in the anterior PSM, correlating in time and space with somite boundary formation $^{26}$. These results provided the first evidence supporting the long-held clock and wavefront hypothesis ${ }^{25}$.

Nowadays, the clock is regarded as a genetic network composed of cell-autonomous and cell-to-cell signaling components, spanning multiple cells. Most genes involved are from the Notch, Fgf, and Wnt signaling pathways ${ }^{28,29}$ yet vary amongst model species such as chick, zebrafish, and mouse ${ }^{30}$.

\section{Time to space translation}

The segmentation clock oscillates in time with a sinusoidal curve, whose phase is locally synchronized between neighboring cells. According to the Cooke and Zeeman ${ }^{25}$ model, as the wavefront passes down the PSM, it interacts with the clock, causing cells within the same period of oscillation to differentiate and become part of the same segment. This interaction is proposed to activate a developmental program that yields the formation of an epithelial somite in the anterior PSM.

This theoretical framework has provided an explanation for how the embryo could translate the information encoded in the temporal periodicity of oscillations of individual cells onto a spatially periodic pattern of segmentation from head to tail along the PSM. This model presents two important predictions: (i) each segment length $(S)$ is determined by the period of the clock $(T)$ and the velocity of the wavefront's progress across the PSM (v), i.e. $S=v T$, and (ii) the total number of segments in the embryo $(n)$ is set by the total duration of the segmentation process $(d)$ and the period of the clock $(T)$, i.e. $n=d / T^{31}$. This model places the period of the clock in a central role for determining the length and overall anatomy of the embryo ${ }^{25,27,32}$. To form the correct number of somites, regardless of the differences in embryo size, both the period of the clock and the speed of the wavefront must be regulated in proportion to the overall length of the $\mathrm{PSM}^{25}$.

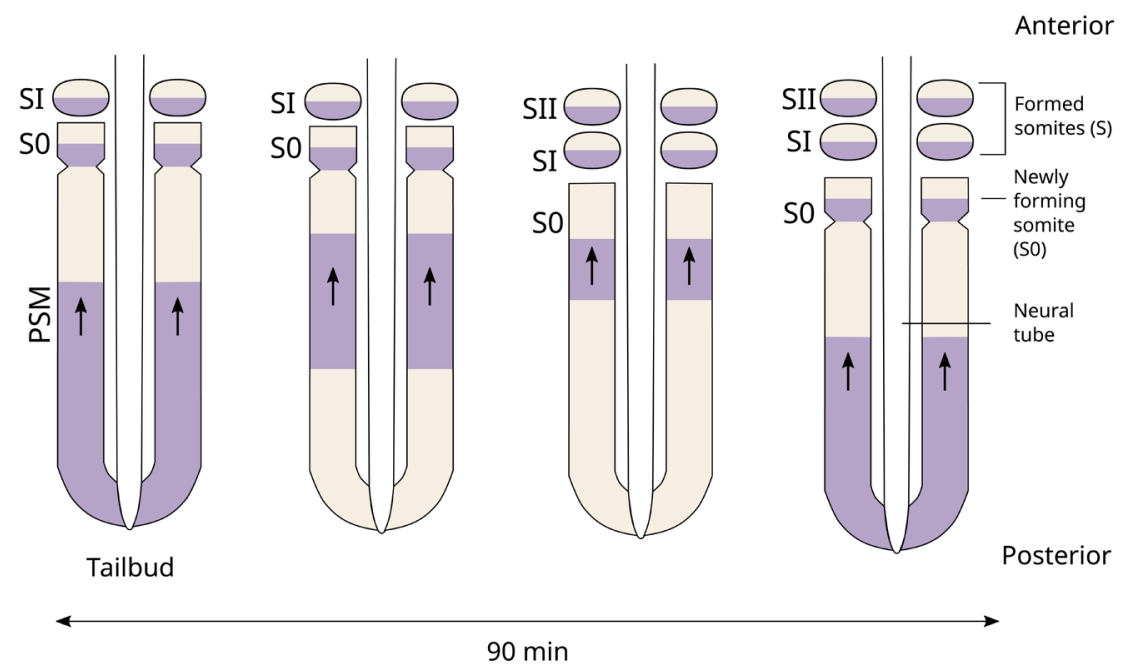

Figure 2. Time to space translation. Kinematic waves of gene expression sweep the A-P axis, arresting anteriorly, followed by somite formation. 
Currently, new models contemplate the fact that the kinematic wave of clock expression narrows as it sweeps from the posterior to the anterior PSM, gradually slowing the clock anteriorly, with peaks of clock expression separated by one segment length in the anterior $\mathrm{PSM}^{27,33-36}$.

\section{Alternative models for segmentation}

Three relevant alternative mechanisms to transform oscillations into spatial stripes have been proposed:

(i) A Turing-Hopf mechanism has been shown by Hans Meinhardt to produce striped patterns from oscillations, provided that a gradient generates the first two stripes ${ }^{37}$.

(ii) Similarly, Murray and co-workers demonstrated that an oscillator phase-gradient can also transform the oscillations into spatial patterns $^{38}$. This proposal gained more strength from a recent study suggesting that such a phase-gradient mechanism, rather than a wavefront, may be involved in freezing oscillations in vertebrate segmentation $^{39}$ (vide infra).

(iii) More recently, Cotterell et al. ${ }^{40}$ proposed the Progressive Oscillatory Reaction Diffusion (PORD) model. This elegant mathematical model is also a Turing mechanism, yet it overcomes the shortcomings of Meinhardt's model ${ }^{37}$; namely, the PORD model is able to describe the scaling of the somites with body size, and it can generate cell-autonomous oscillations without diffusion. Additionally, the PORD model displays enough flexibility to switch between simultaneous and sequential segmentation $^{41-43}$, contrary to Murray's coupled oscillators model $^{38}$.

Most notably, in all of these models, the wavefront is an emergent property of the time-space transformation rather than a causal agent $^{16,40}$. Further experimental research is required to help define the models that provide the most insight into the segmentation mechanism.

\section{Recent experimental insights into vertebrate segmentation}

\section{Segment scaling}

Lauschke and colleagues proposed in 2013 a segment scaling mechanism based on a Phase-Gradient encoding, i.e. the gradual shift in the oscillation phase of PSM cells encodes information for the spatial patterning of the PSM tissue ${ }^{39}$. Contrary to long-range molecular gradients (such as the wavefront proposed by Cooke and Zeeman), a phase-gradient describes the distribution of a dynamic cellular state. This provides a possible explanation for how the embryo maintains stable segment proportions despite overall changes in size, e.g. due to normal embryo growth or as observed when, after experimental reduction of embryo size, the total number of segments remains unaltered and the segments become proportionally smaller ${ }^{44,45}$.

Using their newly developed ex vivo experimental setting composed by a quasi-monolayer of mouse primary PSM cells (mPSM) combined with real-time gene expression imaging, the authors observed that (i) the period of oscillation in the central mPSM remains constant regardless of PSM length, (ii) the velocities of kinematic waves change linearly with overall mPSM length (larger samples display proportionally faster kinematic waves, indicating that oscillatory activity adapts to match the spatial context in which it occurs), and (iii) the phase-gradient slope is predictive of segment size.

Overall, this study suggests that segment size definition could be encoded at the level of phase differences between PSM cells, without the requirement for a molecular gradient, also known as a wavefront.

\section{Period of segmentation}

In 2014, Soroldoni and co-workers set out to study the period of segmentation. Using real-time measurements of genetic oscillations in zebrafish embryos, they showed that the time scale of genetic oscillations is not sufficient to explain the period of segmentation as the segmentation clock postulates ${ }^{46}$. Instead, the rate of tissue shortening provides the second time scale necessary to determine the period of segmentation through what they termed a "Doppler effect" modulated by a gradual change in the oscillation profile across the tissue.

Briefly, they found that (i) both anterior and posterior PSM oscillate, albeit with different amplitudes, (ii) oscillations in the posterior PSM are slower than in the anterior PSM (i.e. there is not a single well-defined period for the segmentation clock), (iii) the period of anterior PSM oscillations matches the period of segmentation, and (iv) there is a substantial shortening of the PSM over time, leading to a relative motion of the anterior end of the PSM toward the posterior end (where the waves arrest), hence creating a "Doppler effect" due to the shortening of the time interval between wave onset and arrest ${ }^{46}$.

Overall, the authors conclude that the rhythm of sequential segmentation is an emergent property controlled by three variables: the period of the individual genetic oscillators, the change of the kinematic wavelength (i.e. oscillation profile), and the shortening of the PSM length. Notably, the authors remark that such a "Doppler effect" is incompatible with the previously proposed Phase-Gradient scaling mechanism, since the latter requires that the number of waves along the PSM remains constant, whereas this study shows that, at least in zebrafish, the number of waves changes between anterior and posterior PSM.

\section{Segmentation clock dynamics}

In 2015, Shih et al. ${ }^{36}$ studied, in vivo, the dynamics of the clock slowing down relative to somite boundary formation as it moves anteriorly through the $\mathrm{PSM}^{36}$. For this, they followed the PSM segmentation clock oscillations in real-time, with single-cell resolution, in zebrafish embryos.

By focusing on cells that eventually form each somite boundary, they showed that (i) in vivo, the clock gradually slows down in the more anterior PSM cells, creating a distribution of oscillation phases-a spatial and temporal phase-gradient-where cells at one-somite distance are in opposite phases of clock expression, (ii) the clock wave increases in amplitude for the final two 
oscillations, and (iii) PSM cells oscillate until they incorporate into somites.

Most importantly, the authors discuss the lack of experimental evidence for the theoretical "arrest-front" causing oscillations to smoothly stop in the anterior PSM by the posteriorly progressing wavefront postulated by the Clock and Wavefront model ${ }^{25}$. Instead, they propose the Clock Wave Stopping model. This proposal postulates that the segmentation clock itself may play a role in determining the wavefront by creating a signal directly encoded by the phase-gradient, with a two-somite periodicity ${ }^{36}$. This is in line with the suggestion from Lauschke et al. ${ }^{39}$.

This model is based on one important observation: within a given forming somite, individual cells stop oscillating in discrete groups in a posterior to anterior direction (P-A), i.e. in the same direction as the waves of clock expression and not in the opposite direction, as would be expected from an A-P wavefront stopping signal. In this Clock Wave Stopping model, cells in the anterior PSM continue to oscillate with their neighbors, regardless of future somite position, consistent with the observations that synchrony is regulated by Delta-Notch interactions ${ }^{47,48}$.

\section{Autonomous segmentation clock}

In early 2016, Webb et al. ${ }^{31}$ addressed the longstanding question of whether individual PSM cells are able to sustain autonomous oscillations without the external input from neighboring cells.

To this end, the authors recorded the expression of Herl in single cells from a transgenic reporter cell line obtained from the tailbud of zebrafish, showing that the individual cells are capable of autonomous genetic oscillations in vitro, in the absence of intercellular communication, albeit with substantial variability (noise) ${ }^{31}$. When comparing these autonomous oscillator data with the oscillations at the tissue level in intact zebrafish embryos (from Soroldoni et $\left.a l .^{46}\right)$, the authors concluded that individual cells have a longer period (ca. twofold slower) and are less precise than the population at the tissue level. This shows the importance of synchronization and coupling for the proper working of the segmentation clock.

\section{Self-organized spatiotemporal waves}

Also in 2016, Tsiairis and Aulehla ${ }^{49}$ presented compelling evidence that PSM cells can self-organize from disordered initial conditions. For this study, the authors dissociated the PSM from several mouse embryos into single cells and used the randomized cell suspension to generate dense cell re-aggregates. These were then cultured and subjected to real-time imaging and quantification of signaling activity using the dynamic Notch signaling reporter LuVeLu (Venus fluorescence driven from the lunatic fringe promoter $)^{49}$.

They reported several relevant findings, from which we highlight the following: (i) after 5-6 hours of culture, cells synchronize and exhibit in-phase oscillations in multiple foci that formed within each re-aggregate, (ii) self-organized foci recapitulate spatiotemporal organization of in vivo PSM, indicating that each focus represents miniature PSM (emerging PSM) that forms spontaneously upon randomization and re-aggregation, (iii) the collective synchronization of the cells corresponds to the arithmetic average of the input oscillator frequencies (i.e. it depends on frequencies of the input cell population), as predicted in models for coupled phase oscillators ${ }^{50}$, rather than matching the highest frequency of potential pacemaker cells, and (iv) upon DAPT treatment (a chemical inhibitor of Notch signaling), randomized PSM cells fail to synchronize, in agreement with previous in vivo findings ${ }^{51}$; however, the individual cells maintained oscillatory activities with amplitudes similar to the untreated ones.

Overall, this report indicates that, after randomization, individual mouse PSM cells self-organize into ordered macroscopic miniature PSM structures that are capable of tuning oscillation dynamics in response to surrounding cells, leading to collective synchronization with an average frequency, re-establishing wavelike patterns of gene activity.

\section{Control of the segmentation clock period}

Later in the same year, Liao et al. ${ }^{52}$ asked whether an increase in Delta-Notch signaling causes a change in the segmentation period. To answer this, they generated transgenic zebrafish lines with a range of extra copies of a transgene containing the deltaD locus (together with its full genomic regulatory region) and measured the segmentation period by multiple embryo time-lapse microscopy ${ }^{52}$.

They found that only the highest level of DeltaD expression (in the Damascus zebrafish line containing ca. 100 copies of deltaD-venus transgene) produces altered oscillating gene expression wave patterns and shorter segmentation periods (6.5\% faster), generating embryos with more, and shorter, body segments. Moreover, the effect on period was lost by incubating Damascus embryos with DAPT (Notch intracellular domain blocker), showing that the observed phenotype is indeed modulated by the overexpression of Delta-Notch molecular players.

The contribution of the proposed "Doppler effect" 4 on the observed change in segmentation period was also evaluated, showing that the alteration of the wave pattern, and not changes in the rate of tissue shortening, is responsible for the majority of the observed period difference.

Finally, the authors put forward a simplified model of coupled oscillators with time delay to explain the shorter segmentation period. Briefly, the coupling strength (i.e. the number of activated ligand-receptor pairs over time) is expected to increase as a consequence of the over-expression of DeltaD, and the time delay in the coupling is not negligible (i.e., it is significant the time taken to transfer the signal from one cell to another owing to the time required to synthesize and traffic Delta proteins). The numerical simulation of such parameter changes leads to a stable timeperiodic wave pattern with an increased number of waves and a shortened anterior wavelength, as experimentally observed in the Damascus line.

Thus, this study hints that the Delta-Notch signaling, besides synchronizing oscillators, seems to alter the segmentation period by affecting the wavelength of the tissue's spatial pattern. However, this issue is not easy to address, since several alternative outcomes arise from changing the Delta-Notch signaling. For instance, a lengthening of the period due to a reduction in Delta-Notch signaling is observed in zebrafish. However, mouse segmentation is faster with the blockade of Notch, an outcome predicted only if 
the length of the time delay in the coupling was shorter than half the period ${ }^{34,53}$.

\section{Open questions}

Segmentation has been extensively studied over the years. However, some fundamental questions remain unanswered, while new ones are being asked, most of them fueled by newly developed experimental techniques such as high-resolution live imaging, single cell tracking systems, and customized ex vivo cell culture assays. Here we compile some of the open questions regarding the inner workings of the vertebrate segmentation clock. The questions are grouped according to Oates' Three Tier model, which organizes the components of the segmentation clock into three different scales: single cell oscillators, local synchronization, and global control of timing and pattern ${ }^{27}$.

\section{Cellular oscillator}

Q1 Recently, it has been shown in zebrafish that single cells carrying a herl-yfp transgene can oscillate autonomously ${ }^{31}$. However, it remains unknown if this is a particular feature of this organism, or if it is an intrinsic characteristic of the segmentation clock cells and hence observed in other species (this has been attempted in chick ${ }^{54}$ and mouse ${ }^{55}$ but without definite conclusions owing to the technological limitations at the time).

\section{Local synchrony}

Q2 | Wave patterns arising from individual oscillators require the establishment of a spatial profile in their phases. How are these wave patterns regulated?

Q3 | The Delta-Notch intercellular signaling pathway is associated with multiple processes, namely lateral inhibition, border formation, and local synchronization. How is the Delta-Notch signaling accomplishing these multiple outcomes?

\section{Global control}

Q4 In vertebrates, the wavefront has been shown to be influenced by gradients of Wnt and Fgf signaling coming from the caudal end and a counter-gradient of retinoic acid (RA) from the somites. How do oscillating cells use and interpret these signaling gradients as stop signals to arrest the oscillation?
Q5 | In vertebrates, embryo segmentation occurs simultaneously with body elongation. Is it possible to disentangle these two processes in order to study them separately?

Q6 | The first five somites are not sequentially formed like the ones from the trunk ${ }^{43}$. Instead, they form almost simultaneously and without cyclical expression of "clock genes" ${ }_{56}$. Is there an alternative mechanism responsible for occipital somite formation?

Q7 Recently, relevant challenges have been made to the clock and wavefront model. Particularly important is the fact that, in order to fully grasp the global mechanism underlying segmentation, it is necessary not only to study gene expression dynamics but also to integrate cellular processes like division, movement, and differentiation ${ }^{57}$. Such a comprehensive theoretical framework would generate an invaluable tool to create new hypotheses and test old ones.

\section{Author contributions}

All authors wrote, reviewed, and edited the final manuscript and have agreed to its final content.

\section{Competing interests}

The authors declare that they have no competing interests.

\section{Grant information}

This work has been supported by the Portuguese Fundação para a Ciência e Tecnologia, fellowships SFRH/BD/84825/2012 to TPA, SFRH/BD/32966/2006 to RM, and PTDC/BEX-BID/5410/2014 to ID, and grants PTDC/BIM-MED/1063/2012 to IP and UID/ BIM/04773/2013 to CBMR.

The funders had no role in study design, data collection and analysis, decision to publish, or preparation of the manuscript.

\section{Acknowledgements}

TPA, RM, ID, and IP would like to respectfully thank Regina Pais de Azevedo, Dília de Andrade Magno, Glória dos Santos (Duarte), and Amélia Marques Palmeirim, respectively, for developing them. ID would also like to thank Rita Bastos for all the stimulating discussions and helpful scientific curiosity.
1. Graham A, Butts T, Lumsden A, et al:: What can vertebrates tell us about segmentation? Evodevo. 2014; 5: 24. ISSN 2041-9139. PubMed Abstract | Publisher Full Text | Free Full Text

2. Malpighi M: Dissertatio epistolica de formatione pulli in ovo. Apud Joannem Martyn, 1673. Reference Source

3. Verbout AJ: A critical review of the 'neugliederung' concept in relation to the development of the vertebral column. Acta Biotheor. 1976; 25(4): 219-258. ISSN 1572-8358.

PubMed Abstract | Publisher Full Text

4. Balfour FM: A treatise on comparative embryology. by Francis M. Balfour, volume 1. London, Macmillan and Co, 1881, Forms v. 2-3 of the "Memorial ed." of the author's works, published London, 1885. Reference Source
5. Christ B, Ordahl CP: Ordahl Early stages of chick somite development. Anat Embryol. 1995; 191(5): 381-396. PubMed Abstract | Publisher Full Text

6. Davis GK, Patel NH: The origin and evolution of segmentation. Trends Genet 1999; 15(12): M68-M72.

Publisher Full Text

7. Eernisse DJ, Albert JS, Anderson FE: Annelida and arthropoda are not sister taxa: a phylogenetic analysis of spiralian metazoan morphology. Syst Biol. 1992; 41(3): 305-330.

Publisher Full Text

8. Aguinaldo AM, Turbeville JM, Linford LS, et al.: Evidence for a clade of nematodes, arthropods and other moulting animals. Nature. 1997; 387(6632): 489-493.

PubMed Abstract | Publisher Full Tex 
9. St Johnston D, Nüsslein-Volhard C: The origin of pattern and polarity in the Drosophila embryo. Cell. 1992; 68(2): 201-219.

PubMed Abstract | Publisher Full Text

10. Stollewerk A, Schoppmeier M, Damen WG: Involvement of Notch and Delta genes in spider segmentation. Nature. 2003; 423(6942): 863-865. ISSN 0028-0836. PubMed Abstract | Publisher Full Text

11. Sarrazin AF, Peel AD, Averof M: A segmentation clock with two-segment periodicity in insects. Science. 2012; 336(6079): 338-341. ISSN 1095-9203. PubMed Abstract | Publisher Full Text

12. Tautz D: Segmentation. Dev Cell. 2004; 7(3): 301-312. PubMed Abstract | Publisher Full Text

13. Peel AD, Chipman AD, Akam M: Arthropod segmentation: beyond the Drosophila paradigm. Nat Rev Genet. 2005; 6(12): 905-916. ISSN 1471-0056. PubMed Abstract | Publisher Full Text

14. McGregor AP, Pechmann M, Schwager EE, et al.: An ancestral regulatory network for posterior development in arthropods. Commun Integr Biol. 2009 2(2): 174-176.

PubMed Abstract | Publisher Full Text | Free Full Text

15. De Robertis EM, Sasai $\mathrm{Y}$ : A common plan for dorsoventral patterning in bilateria. Nature. 1996; 380(6569): 37-40.

PubMed Abstract | Publisher Full Text

16. Ten Tusscher KH: Mechanisms and constraints shaping the evolution of body plan segmentation. Eur Phys J E Soft Matter. 2013; 36(5): 54. ISSN 1292-895X. PubMed Abstract | Publisher Full Text

17. Couso JP: Segmentation, metamerism and the Cambrian explosion. Int J Dev Biol 2009: 53(8-10): 1305-1316.

PubMed Abstract | Publisher Full Text

18. Chipman AD: Parallel evolution of segmentation by co-option of ancestral gene regulatory networks. Bioessays. 2010; 32(1): 60-70.

PubMed Abstract | Publisher Full Text

19. Clark E, Peel AD: Evidence for the temporal regulation of insect segmentation by a conserved set of developmental transcription factors. bioRxiv. 2017; 14515 Publisher Full Text

20. Richmond DL, Oates AC: The segmentation clock: inherited trait or universal design principle? Curr Opin Genet Dev. 2012; 22(6): 600-606. ISSN 1879-0380. PubMed Abstract | Publisher Full Text

21. Jenner RA, Wills MA: The choice of model organisms in evo-devo. Nat Rev Genet 2007: 8(4): 311-9. PubMed Abstract | Publisher Full Text

22. Vroomans $\mathrm{RM}$, Hogeweg $\mathrm{P}$, Ten Tusscher $\mathrm{KH}$ : In silico evo-devo: reconstructing stages in the evolution of animal segmentation. EvoDevo. 2016; 7(1): 14 PubMed Abstract | Publisher Full Text | Free Full Text

23. F Davies J: Using synthetic biology to explore principles of development. Development. 2017; 144(7): 1146-1158. PubMed Abstract | Publisher Full Text | F1000 Recommendation

24. $F$ Hunding A, Baumgartner S: Ancient role of ten-m/odz in segmentation and the transition from sequential to syncytial segmentation. Hereditas. 2017 154(1): 8. ISSN 1601-5223.

PubMed Abstract | Publisher Full Text | Free Full Text | F1000 Recommendation

25. Cooke J, Zeeman EC: A clock and wavefront model for control of the number of repeated structures during animal morphogenesis. J Theor Biol. 1976; 58(2): 455-476.

PubMed Abstract | Publisher Full Text

26. Palmeirim I, Henrique D, Ish-Horowicz D, et al: Avian hairy gene expression identifies a molecular clock linked to vertebrate segmentation and somitogenesis. Cell. 1997; 91(5): 639-648. ISSN 0092-8674. PubMed Abstract | Publisher Full Text

27. Oates AC, Morelli LG, Ares S: Patterning embryos with oscillations: structure, function and dynamics of the vertebrate segmentation clock. Development. 2012; 139(4): 625-639. ISSN 1477-9129. PubMed Abstract | Publisher Full Tex

28. Dequéant ML, Glynn E, Gaudenz K, et al: A complex oscillating network of signaling genes underlies the mouse segmentation clock. Science. 2006; signaling genes underlies the mouse seg 314(5805): 1595-1598. ISSN 1095-9203
PubMed Abstract | Publisher Full Text

29. Aulehla A, Johnson RL: Dynamic expression of lunatic fringe suggests a link between notch signaling and an autonomous cellular oscillator driving somite segmentation. Dev Biol. 1999; 207(1): 49-61. PubMed Abstract | Publisher Full Text

30. Krol AJ, Roellig D, Dequéant ML, et al: Evolutionary plasticity of segmentation clock networks. Development. 2011; 138(13): 2783-2792. PubMed Abstract | Publisher Full Text | Free Full Text

31. Webb AB, Lengyel IM, Jörg DJ, et al.: Persistence, period and precision of autonomous cellular oscillators from the zebrafish segmentation clock. eLife. 2016; 5: pii: e08438. ISSN 2050-084X

PubMed Abstract | Publisher Full Text | Free Full Text

32. Slack JMW: From Egg to Embryo: Regional Specification in Early Development. 1991; chapter 3: 65. Cambridge University Press, ISBN 9780521409438. Reference Source

33. Giudicelli F, Ozbudak EM, Wright GJ, et al:: Setting the tempo in development: an investigation of the zebrafish somite clock mechanism. PLOS Biol. 2007; 5(6): e150. ISSN 1545-7885.

PubMed Abstract | Publisher Full Text | Free Full Text
34. Morelli LG, Ares S, Herrgen L, et al.: Delayed coupling theory of vertebrate segmentation. HFSP J. 2009; 3(1): 55-66.

PubMed Abstract | Publisher Full Text | Free Full Text

35. F Ay A, Holland J, Sperlea A, et al.: Spatial gradients of protein-level time delays set the pace of the traveling segmentation clock waves. Development. 2014; 141(21): 4158-4167.

PubMed Abstract | Publisher Full Text | Free Full Text | F1000 Recommendation

36. F Shih NP, François P, Delaune EA, et al.: Dynamics of the slowing segmentation clock reveal alternating two-segment periodicity. Development. 2015; 142(10): 1785-1793.

PubMed Abstract | Publisher Full Text | Free Full Text | F1000 Recommendation

37. Hans M: Models of Segmentation. 1986; chapter 14: 179-189. Springer US, Boston, MA, ISBN 978-1-4899-2013-3.

Publisher Full Text

38. Murray PJ, Maini PK, Baker RE: The clock and wavefront model revisited. J Theor Biol. 2011; 283(1): 227-238 ISSN 1095-8541. PubMed Abstract | Publisher Full Text

39. $\mathrm{F}$ Lauschke VM, Tsiairis $\mathrm{CD}$, François $\mathrm{P}$, et al:: Scaling of embryonic patterning based on phase-gradient encoding. Nature. 2013; 493(7430): 101-105. PubMed Abstract | Publisher Full Text | F1000 Recommendation

40. F Cotterell J, Robert-Moreno A, Sharpe J: A Local, Self-Organizing ReactionDiffusion Model Can Explain Somite Patterning in Embryos. Cell Syst. 2015; 1(4): $257-269$

PubMed Abstract | Publisher Full Text | F1000 Recommendation

41. Naiche LA, Holder N, Lewandoski N: FGF4 and FGF8 comprise the wavefron activity that controls somitogenesis. Proc Natl Acad Sci U S A. 2011; 108(10): $4018-4023$.

PubMed Abstract | Publisher Full Text | Free Full Text

42. Dias AS, de Almeida I, Belmonte JM, et al.: Somites without a clock. Science. 2014; 343(6172): 791-795

PubMed Abstract | Publisher Full Text | Free Full Text

43. Maschner A, Krück S, Draga M, et al.: Developmental dynamics of occipital and cervical somites. J Anat. 2016; 229(5): 601-609.

PubMed Abstract | Publisher Full Text

44. Cooke $\mathrm{J}$ : Control of somite number during morphogenesis of a vertebrate, Xenopus laevis. Nature. 1975; 254(5497): 196-199.

PubMed Abstract | Publisher Full Text

45. Tam PP: The control of somitogenesis in mouse embryos. J Embryol Exp Morphol. 1981; 65(Suppl): 103-128. ISSN 0022-0752.

PubMed Abstract

46. Soroldoni D, Jörg DJ, Morelli LG, et al:: Genetic oscillations. a doppler effect in embryonic pattern formation. Science. 2014; 345(6193): 222-225. ISSN 1095-9203. PubMed Abstract | Publisher Full Text

47. Jiang YJ, Aerne BL, Smithers L, et al:: Notch signalling and the synchronization of the somite segmentation clock. Nature. 2000; 408(6811): 475-9. PubMed Abstract | Publisher Full Text

48. Horikawa K, Ishimatsu K, Yoshimoto E, et al.: Noise-resistant and synchronized oscillation of the segmentation clock. Nature. 2006; 441(7094): 719-723. ISSN 1476-4687.

PubMed Abstract | Publisher Full Text

49. F Tsiairis CD, Aulehla A: Self-Organization of Embryonic Genetic Oscillators into Spatiotemporal Wave Patterns. Cell. 2016; 164(4): 656-667. PubMed Abstract | Publisher Full Text | Free Full Text | F1000 Recommendation

50. Kuramoto Y: Chemical Oscillations, Waves, and Turbulence. Dover Books on Chemistry Series. Dover Publications, 2003. ISBN 9780486428819. Reference Source

51. Delaune EA, François $P$, Shih NP, et al:: Single-cell-resolution imaging of the impact of Notch signaling and mitosis on segmentation clock dynamics. Dev Cell. 2012; 23(5): 995-1005.

PubMed Abstract | Publisher Full Text | Free Full Text

52. F Liao BK, Jörg DJ, Oates AC: Faster embryonic segmentation through elevated Delta-Notch signalling. Nat Commun. 2016; 7: 11861. PubMed Abstract | Publisher Full Text | Free Full Text | F1000 Recommendation

53. Kim W, Matsui T, Yamao M, et al:: The period of the somite segmentation clock is sensitive to Notch activity. Mol Biol Cell. 2011; 22(18): 3541-3549. PubMed Abstract | Publisher Full Text | Free Full Text

54. Maroto M, Dale JK, Dequéant ML, et al:: Synchronised cycling gene oscillations in presomitic mesoderm cells require cell-cell contact. Int J Dev Biol. 2005; 49(2-3): 309-315. ISSN 0214-6282. PubMed Abstract | Publisher Full Text

55. Masamizu $Y$, Ohtsuka T, Takashima $Y$, et al:: Real-time imaging of the somite segmentation clock: revelation of unstable oscillators in the individual presomitic mesoderm cells. Proc Natl Acad Sci U S A. 2006; 103(5): 1313-1318. ISSN 0027-8424.

PubMed Abstract | Publisher Full Text | Free Full Text

56. Rodrigues S, Santos J, Palmeirim I: Molecular characterization of the rostralmost somites in early somitic stages of the chick embryo. Gene Expr Patterns. 2006; 6(7): 673-677. ISSN 1567-133X.

PubMed Abstract | Publisher Full Tex

57. F Uriu K: Genetic oscillators in development. Dev Growth Differ. 2016; 58(1):

PubMed Abstract | Publisher Full Text | F1000 Recommendation 


\section{Open Peer Review}

\section{Current Peer Review Status:}

\section{Editorial Note on the Review Process}

Faculty Reviews are review articles written by the prestigious Members of Faculty Opinions. The articles are commissioned and peer reviewed before publication to ensure that the final, published version is comprehensive and accessible. The reviewers who approved the final version are listed with their names and affiliations.

\section{The reviewers who approved this article are:}

\section{Version 1}

1. Yoshiko Takahashi

Kyoto University, Kyoto, Japan

Competing Interests: No competing interests were disclosed.

\section{Michael Akam}

University of Cambridge, Cambridge, UK

Competing Interests: No competing interests were disclosed.

\section{Robb Krumlauf}

Stowers Institute for Medical Research, Kansas City, Missouri, USA

Competing Interests: No competing interests were disclosed.

The benefits of publishing with F1000Research:

- Your article is published within days, with no editorial bias

- You can publish traditional articles, null/negative results, case reports, data notes and more

- The peer review process is transparent and collaborative

- Your article is indexed in PubMed after passing peer review

- Dedicated customer support at every stage

For pre-submission enquiries, contact research@f1000.com 